\title{
SENIORS IN CITIES AND SENIOR-FRIENDLY CITIES ANALYSIS FOR SELECTED POLISH CITIES - ROBUST TAXONOMIC APPROACH
}

\section{Grażyna Trzpiot}

University of Economics in Katowice, Katowice, Poland

e-mail: grazyna.trzpiot@ue.katowice.pl

ORCID: 0000-0002-5129-5764

\section{(C) 2020 Grażyna Trzpiot}

This is an open access article distributed under the Creative Commons Attribution-NonCommercial-NoDerivs license (http://creativecommons.org/licenses/by-nc-nd/3.0/)

DOI: 10.15611/eada.2020.2.03

JEL Classification: C38, J11, R15

\begin{abstract}
The purpose of the article is to assess selected large cities in Poland as senior-friendly. Using the municipal population forecast for 2017-2030 published in 2017, together with the available database, own analyses were made for selected cities in Poland. Additionally for the description of 'senior-friendly' cities, it was assumed that the starting point is the WHO definition, which indicated four main criteria determining whether a given city can be considered to be friendly to the elderly. In a city friendly to seniors, the principles, services, environment and structures built up support the active ageing process and avail it for the residents. For the purposes of the research, taking into account the above objectives and based on published sources, a descriptive model was created. The study assessed selected Polish cities as senior-friendly cities, using the robust taxonomic approach.
\end{abstract}

Keywords: elderly people, seniors' safety, robust taxonomic analysis.

\section{Introduction}

The world's population is currently undergoing two historically significant demographic shifts - rapid ageing and urbanization. As a result, the number of older people living in urban environments is growing dramatically (World Health Organization, 2015, p. 2). Older people are a resource for their families, communities and economies in supportive and enabling living environments. WHO regards active ageing as a lifelong process shaped by several factors that, alone and acting together, ensure good health, participation and security in older adult life.

In most countries, the fastest growing age group is 60 and older. The number of people in this age group is expected to increase from 841 million in 2013 to more than 2 billion in 2050, representing an almost doubling of the proportion of this population worldwide from 11.7 percent in 2013 to 21.1 percent in 2050 (World 
population ageing, 2013). Urban populations are also steadily increasing around the globe, and in much greater numbers in less developed parts of the world.

The challenges and opportunities that come with urbanization (World Health Organization, 2010) and with population ageing (World Health Organization, 2011), respectively, have been well recognized, however the impacts of their convergence are only beginning to be understood (World Health Organization, 2015).

Urban quality of life is currently conceptualized in principally economic terms. As the decline in manufacturing activities, the rise of the service and knowledge economy, the growing importance of accessibility and globalizing processes continue to reconfigure the economic competition between cities, quality of life enters the discourse primarily as a means to attract high-skilled workers and improve the city's economic prospects. Local governments increasingly seek partnerships with local and foreign capital, reorganizing institutions and tasks to attract capital, including the 'selling of place', strengthening place promotion and marketing efforts. The rhetoric clearly welcomes wealthy, creative, and highly-skilled people; disadvantaged and low skilled groups receive less attention in the making of places. Especially with respect to inner city areas, high quality of life is promoted as space for 'clean' and convenient consumption with positive atmosphere and glossy image, a wide spectrum of theoretical aspects of urban everyday life reminds us that, while variety of jobs, quality of public spaces, range of shops and services, cultural facilities and public transport are important, place characteristics and more subjective aspects such as safe neighbourhoods, well-being, community prospects, social cohesion, happiness, satisfaction and social and spatial justice are equally crucial determinants of urban quality of life.

These elements of urban quality of life - and how they are experienced by diverse formations of urban inhabitants - seem to be absent from, if not at odds with, the dominant discourse in rankings, policy and practice. Urban life, social cohesion and complexity are at risk in the dynamics of modernization and adaptation strategies of cities especially for elderly citizens.

For this paper, in the research, taking into account the above objectives and based on published sources, a descriptive model was created. The study assessed selected Polish cities as senior-friendly cities, using the robust taxonomic approach.

\section{Seniors in cities}

The individual process of passing through a senior period of life is most often conditioned by society and can be considered within specific social structures. The ageing process will be affected by income levels, education, residence or type of family. Ageing can also be treated as a social process, conditioned by the biological and physiological changes taking place in the human body, because the limits of old age are determined not only by biological changes, but also by society (Błędowski, 2002, s. 62). 
It should be emphasized that the division of the last stage of human life changes as life increases and life improves in the elderly population. Currently, demography uses the division of old age into three phases:

- young old - people aged 60/65-74,

- old people - people aged 75-84,

- the oldest old - people aged 85 and more.

The increase in the share of older people has an impact on virtually all areas of socio-economic life. In 2016, seniors aged 60 and over accounted for $23.6 \%$ of the population, and in $2017-24.2 \%$ of the Polish population. In the subpopulation of older people, the largest group (almost one-third) are 60 to64-year-olds and - in the last over a quarter of a century - their number increased by one third. It should be noted that (Table 1) almost $18 \%$ of older people are at least 80 years old ${ }^{1}$.

Table 1. Population by age in 2017

\begin{tabular}{|c|c|c|c|c|c|c|c|c|c|c|}
\hline & $\begin{array}{c}\text { Total } \\
\text { [in thousands] }\end{array}$ & $\begin{array}{l}\text { Urban } \\
\text { areas }\end{array}$ & $\begin{array}{l}\text { Rural } \\
\text { areas }\end{array}$ & males & females & $\begin{array}{c}\text { Total } \\
{[\%]}\end{array}$ & $\begin{array}{l}\text { Urban } \\
\text { areas }\end{array}$ & $\begin{array}{l}\text { Rural } \\
\text { areas }\end{array}$ & males & females \\
\hline Total & 38433.6 & 23109.3 & 15324.3 & 18593.2 & 19840.4 & \multicolumn{5}{|c|}{ total $=100$} \\
\hline $\begin{array}{l}\text { At age } \\
60 \text { and } \\
\text { more in } \\
\text { the total } \\
\text { popula- } \\
\text { tion }\end{array}$ & 9293.6 & 6068.4 & 3225.2 & 3869.3 & 5424.3 & 24.2 & 26.3 & 21.0 & 20.8 & 27.3 \\
\hline & & & & & & \multicolumn{5}{|c|}{ At age 60 and more $=100$} \\
\hline $60-64$ & 2773.3 & 1799.0 & 974.3 & 1298.3 & 1475.0 & 29.8 & 29.6 & 30.2 & 33.6 & 27.2 \\
\hline $65-69$ & 2354.0 & 1567.3 & 786.7 & 1050.4 & 1303.6 & 25.3 & 25.8 & 24.4 & 27.1 & 24.0 \\
\hline $70-74$ & 1438.3 & 961.5 & 476.8 & 602.6 & 835.7 & 15.5 & 15.8 & 14.8 & 15.6 & 15.4 \\
\hline $75-79$ & 1085.6 & 704.5 & 381.1 & 410.1 & 675.4 & 11.7 & 11.6 & 11.8 & 10.6 & 12.5 \\
\hline $80-84$ & 872.0 & 556.9 & 315.1 & 294.1 & 577.9 & 9.4 & 9.2 & 9.8 & 7.6 & 10.7 \\
\hline $\begin{array}{l}\text { At age } \\
85 \text { and } \\
\text { more }\end{array}$ & 770.4 & 479.2 & 291.2 & 213.8 & 556.6 & 8.3 & 7.9 & 9.0 & 5.5 & 10.3 \\
\hline
\end{tabular}

Source: based on Local Data Bank., access on 15.09.2019.

${ }^{1}$ Pursuant to the provisions of the Act of 11 September 2015 on the elderly (Journal of Laws 2015, item 1705), the presented demographic data and survey results concern people aged 60 and over. In turn, the results of current reporting include the age group distinguished in the reports, closest to the group specified in the Act. To better illustrate the situation of the discussed population, the information was presented against the background of the total population or compared with persons under 60 years of age. Sometimes additional age categories have been identified in the elderly group. Due to rounding, the data presented in the tables may not add up. 
Among the elderly population, the majority are women (over 58\%), there are 140 per 100 men (for the entire Polish population the feminization ratio is 107). The increasing share of women in the population with age is a consequence of the excess mortality of men and the diversity of life expectancy parameters - women reaching the age of 60 have five years longer life expectancy ahead of them than men.

The numerical superiority of women (Table 2) increases with the transition to subsequent groups of old age, e.g. in the 60-64 age group women constitute over $53 \%$ of the population and the feminization ratio is 114 , and among people aged 85 or over it is over $72 \%$ (there are 260 women and 100 men, in cities 251 and in villages 277).

Table 2. Sex ratio - number of females per 100 males (in 2017)

\begin{tabular}{|l|c|c|c|}
\hline \multicolumn{1}{|c|}{ (Gender ratio) in 2017. } & Total & Urban areas & Rural areas \\
\hline Total & 107 & 111 & 101 \\
\hline At age 60 and more in the total population & 140 & 146 & 129 \\
\hline Age & 114 & 123 & 98 \\
\hline $60-64$ & 124 & 132 & 110 \\
\hline $65-69$ & 139 & 143 & 131 \\
\hline $70-74$ & 165 & 168 & 159 \\
\hline $75-79$ & 197 & 196 & 197 \\
\hline $80-84$ & 260 & 251 & 277 \\
\hline At age 85 and more &
\end{tabular}

Source: based on Local Data Bank.

In addition, it is important to emphasize the shifting - among older people - of the largest percentage of deaths towards increasingly older age groups, which may indicate an improvement in the state of health of the population. At the beginning of the 1990s, among the elderly deceased, the largest percentage were people in the age group $80-84$, and since 2000 it has been the group aged 85 and above. The presented changes are reflected in the increase in the average life expectancy of the population (Informacja o sytuacji osób...).

\section{Senior-friendly cities}

In the case of 'senior-friendly' cities, it was assumed that the starting point is the WHO definition. According to the guidelines, senior-friendly cities are those in which authorities, entrepreneurs and residents (World Health Organization, 2007; Miasta przyjazne starzeniu, 2014):

- take into account the diversity of older people,

- counteract exclusion and promote the contribution of seniors to all areas of life, 
- respect the choices, decisions and way of life of older people,

- anticipate and flexibly respond to the needs of ageing.

The WHO study was based on research conducted in 33 cities of different sizes in 22 countries on each continent. In total, 158 group interviews were conducted with $148560+$ participants, and additionally consultations with 250 carers and 515 service providers. The study covered both the largest metropolises with more than 10 million inhabitants (Mexico, Moscow, Tokyo), large cities the size of London and New York, as well as small ones with several tens of thousands, e.g. Dundalk in Ireland. Poland did not participate in this study.

In each of the 33 cities studied, eight key areas were asked as part of group interviews. The first three: 1) public space, 2) transport and 3) housing, covered the physical environment of the elderly person and their mobility. The next three: 4) social participation (how seniors engage in city life), 5) respect and social integration (how they are perceived by others), 6) civic activity and employment (opportunities for voluntary and professional work), created a social environment for seniors. The last two: 7) communication and information, and 8) environmental support and health services, concerned socio-economic factors and focused on the possibilities of obtaining appropriate support (World Health Organization, 2015).

As part of the study coordinated by the World Health Organization, seniors were questioned in 33 cities in 22 countries on each continent. In the publication summarizing the results (World Health Organization, 2015), eight research topics were separated, divided into three areas:

1. Housing, public transport and public space (parks, cinemas, theatre, etc.) creating the senior's physical environment; 1) public space, 2) transport and 3) housing covered the physical environment of the elderly and its mobility.

2. Social participation (how seniors get involved in the city), respect and social integration (how they are perceived by others), civic activity and employment (opportunities for voluntary and professional work), creating the social environment of the senior; 4) social participation (how seniors engage in city life), 5) respect and social integration (how they are perceived by others), 6) civic activity and employment (opportunities for voluntary and professional work) created the social environment of the seniors.

3. Communication and information as well as environmental support and health care are the elements affecting the lives of the elderly; 7) communication and information; and 8) environmental support and health services concerned socioeconomic factors and focused on the possibilities of obtaining appropriate support.

\section{Senior-friendly cities analysis for selected Polish cities}

The author's own study was conducted in ten large cities. The aim of the study is to assess these selected large cities in Poland as a city attractive/safe/ friendly for seniors.

Therefore, the author used a group of descriptive, macroeconomic variables related to the areas defined in the previous point, i.e. health issues, senior 
environmental safety and personal security in the city space. The study also used statistical data published by the Central Statistical Office of Poland from the BDL database, as well as a taxonomic approach, determining the Taxonomic Measure of City Attractiveness (TMCA), which is a measure of linear order.

Taxonometric development measures allow for replacing the description performed by many diagnostic features with one aggregate size - a synthetic variable. The author designated such a measure, the definitions of which are presented below.

The starting point for its calculation and the basis for consideration here is the matrix $\mathrm{X}$ containing observations of diagnostic features regarding the examined objects:

$$
X=\left[x_{i j}\right],(i=1 \ldots n, j ; 1 \ldots m),
$$

where: $X$ - matrix of observations made on variables describing individual objects, $n, m$ - number of objects and number of variables.

The synthetic development measure $\mathrm{Z}$ is a function that converts the $X$ observation matrix into a vector $z$ :

$$
z=\left[\begin{array}{c}
z_{1} \\
z_{2} \\
\cdots \\
\cdots \\
z_{n}
\end{array}\right] .
$$

Elements of the $z$ vector indicate synthetic measures of development for objects from 1 to $n$. Their values allow ordering objects in a linear manner due to the features describing the level of the studied phenomenon (Hellwig, 1968, pp. 307-327; Trzpiot, Szołtysek, Twaróg, and Ojrzyńska, 2015, pp. 118-127). The first stage of TMCA construction is choosing variables that will be taken into account when assessing cities. The diagnostics variables used to construct $T M C A$ were divided into:

- stimulants - these are the qualities whose higher value indicates a higher level of development,

- destimulants - for them a decrease in value indicates a higher level of development,

- nominants - where the desired level of the examined feature is in a certain range. Due to the fact that in the process of transforming the $X$ matrix into a vector with diagnostic functions added to simplify the calculation, it is convenient to present all the variables with the help of a stimulant. A formula was used for this purpose that complies with the formula: 


$$
x_{i j}=\frac{1}{x_{i j}^{\prime}},
$$

where: $x_{i j}$ - values of destimulants transformed into a stimulant, $x_{i j}^{\prime}-$ original values of destimulants.

After this transformation, the growing values of all features show a more favourable impact on the measure's value, interpreted as the city's attractiveness. The next step is to normalize the $\mathrm{X}$ matrix and present them in the form of normalized $\mathrm{Z}$ matrixes. Such normalization is carried out according to the formula:

$$
z_{i j}=\frac{x_{i j}-\overline{x_{j}}}{S_{j}},
$$

where: $z_{i j}$ - normalized observation $x_{i j}$ from the matrix $\mathbf{X}, x_{i j}$-value of the $i$-th object and $j$-th feature, $\overline{x_{j}}$ - arithmetic mean for the $j$-th feature (variable), $S_{j}$ - standard deviation for the $j$-th variable.

The next step is to create a reference object with the values of the normalized diagnostic variables of the best that were observed in reality. To do this, the largest values from each column of the $\mathrm{Z}$ matrix were selected. The distance of each object from the pattern could be thus calculated. The Euclidean distance, which is expressed by the formula, was used:

$$
d_{i}=\sqrt{\frac{\sum_{j=1}^{m}\left(z_{i j}-z_{0 j}\right)^{2}}{m}},
$$

where: $d_{i}$ - distance of the $i$-th object from the reference object, $z_{i j}$ - normalized observation from the matrix $\mathbf{Z}, x_{0 j}-$ elements of the pattern object, $m$ - number of variables (observations).

The variables (distances) determined in this way are not normalized, they need to be normalized to lead to a situation in which its higher values will indicate a higher level of the studied phenomenon. Most often, this normalization is performed by using the statistical maximum value of the variable $d$, determined according to the formula:

$$
d_{0}=\bar{d}+2 S_{d},
$$

where: $d_{0}$ - variable norm, $\bar{d}$ - arithmetic mean of variable $d, S_{d}$-standard deviation of variable $d$. 
Finally, we calculated TMCA, determined according to the formula:

$$
T M C A_{i}=1-\frac{d_{i}}{d_{o}},
$$

where: $T M C A_{i}-$ synthetic measure of development for the $i$-th object, $d_{i}-$ distance of the $i$-th object from the reference object, $d_{0}-$ variable ensuring that TMCA takes values between 0 and 1 .

The interpretation of the synthetic linear order measure determined in this way is as follows: the higher value of the TMCA measure determined indicates a more positive assessment of the examined city.

For the main part of research the author applied a robust version of TMCA based on a robust estimator of average value of the variables and their differentiation. The author applied median and quarter deviation, and finally noted this synthetic linear order measure as $R-T M C A$.

Using macroeconomic data published annually by the Central Statistical Office and currently available in a digital version via the Local Data Bank (BDL) platform in connection with the topics indicated by $\mathrm{WHO}$, variables were selected from the following areas affecting the safe and active life of older people in cities:

- condition and environmental protection,

- public safety,

- population,

- health protection and social assistance,

- local trade.

Related variables from each of the research areas were selected. Variables were selected from the Local Data Bank. The selected variables from the Local Data Bank are generally aggregate variables for the city, and are expressed in various units, not directly comparable. The first step in the research was to prepare the acquired database so as to obtain comparability of units and comparability of scales. The published values were transformed to obtain comparability of the scales.

The ten biggest cities were analysed: Bydgoszcz, Gdańsk, Katowice, Kraków, Lublin, Łódź, Poznań, Szczecin, Warsaw and Wrocław (data for 2017). The TMCA synthetic measure was built based on the following variables

- X1 Dust emissions/per inhabitant in $t$,

- X2 Gas emissions/per inhabitant in $t$,

- X3A Total impurities retained/in \%,

- X3 Impurities retained in dust reduction devices/in \%,

- X4 Impurities retained in gas pollution abatement equipment/in \%,

- X5 Area with special natural values legally protected/per inhabitant in \%,

- X5B Walking and leisure parks/ha per inhabitant, 
- X6 Expenditure on nature protection $2 /$ per inhabitant in PLN,

- X7 Offences against health and life/per inhabitant,

- X8 Beds in hospitals/per inhabitant,

- X9 Number of pharmacies/per inhabitant,

- X10 Population density,

- X11 Population,

- X11A Change in population per 1000 inhabitants,

- X11B Number of women/number of men,

- X12 Post-working age population/total population,

- X13 Number of permanent markets/per inhabitant,

- X13A Permanent marketplaces area/per inhabitant.

In the study, the variables that have the nature of changes such as destimulants are the variables X1, X2, X7, X11B. Population density and total population were considered stimulants because funding streams for other aspects of cities, such as roads and transport, are linked to these indicators ${ }^{3}$. The determined values of the robust Taxonomic Measure of City Attractiveness for the examined cities are recorded in Table $3^{4}$.

Table 3. $R$-TMCA values for the cities studied

\begin{tabular}{|l|c|c|}
\hline \multicolumn{1}{|c|}{ City } & $R-T M C A$ & Rank \\
\hline Łódź & 0.3624 & 1 \\
\hline Bydgoszcz & 0.3589 & 2 \\
\hline Wrocław & 0.3085 & 3 \\
\hline Warszawa & 0.2925 & 4 \\
\hline Poznań & 0.2098 & 5 \\
\hline Kraków & 0.1570 & 6 \\
\hline Gdańsk & 0.1324 & 7 \\
\hline Katowice & 0.1174 & 8 \\
\hline Lublin & 0.1106 & 9 \\
\hline Szczecin & 0.0287 & 10 \\
\hline
\end{tabular}

Source: own calculation.

${ }^{2}$ Macroeconomic variable: Expenditure on nature protection, is not available in the Local Data Bank (BDL) database. The values of this variable were taken from several publications of voivodeship Statistical Offices for each city respectively: Województwo łódzkie, podregiony, powiaty, gminy, 2018; Województwo kujawsko-pomorskie, podregiony, powiaty, gminy, 2018; Województwo dolnośląskie, podregiony, powiaty, gminy, 2018; Województwo mazowieckie, podregiony, powiaty, gminy, 2018; Województwo wielkopolskie, podregiony, powiaty, gminy, 2018; Województwo małopolskie, podregiony, powiaty, gminy, 2018; Województwo pomorskie, podregiony, powiaty, gminy, 2018; Województwo śląskie, podregiony, powiaty, gminy, 2018; Województwo lubelskie, podregiony, powiaty, gminy, 2018; Województwo zachodniopomorskie, podregiony, powiaty, gminy, 2018.

3 The study is an extension of the research conducted in non-robust way for six cities and 13 variables for data for 2015: (Trzpiot and Szołtysek, 2016, pp. 209-226).

4 The classic version of the analysis was published in the book: (Szołtysek and Trzpiot, 2019). 
According to the variables adopted for the study, a ranking was obtained 3) of the cities described in the context of friendly cities for seniors. The values of variables were obtained from official surveys conducted by the Central Statistical Office, so they are comparable for all cities. The most favourable result turned out to be $R-T M C A=0.3624$, for Łódź, and the lowest score was obtained by Szczecin.

\section{Conclusion}

City attractiveness for seniors:

- can be presented as an aggregate measure - this is due to the multifaceted aspect of security as a perceptible state (subjective security) and the measurement of specific urban phenomena;

- the presented research combined some elements of habitat safety (external health and personal safety), safety of the city space (mainly concerning public spaces) and individual health (and in principle, protection of this health with the potential of medical services and access to pharmaceutical outlets); such a system is determined not only by the reviewed papers and views of the authors of this publication, but also by the available statistical data.

As a result of the conducted research, it was found that it is possible to realistically assess cities friendly for the elderly. The largest cities were selected for research, while maintaining some common criteria. The set of variables can be extended and modified to create more adequate descriptions of changing living conditions in cities for the elderly. The research methodology used is universal.

Age-friendliness of an urban environment is a complex, dynamic and multidimensional concept which is also highly context-dependent. The determinants used in the research have to be understood from a life's course perspective that recognizes that older people are not a homogeneous group and that individual diversity increases with age. From an individual and societal perspective, it is important to remember that the speed of decline can be influenced and may be reversible at any age through individual and public policy measures, such as promoting an age-friendly living environment.

This paper was presented at the conference MSA 2019 which financed its publication. The organization of the international conference "Multivariate Statistical Analysis 2019" (MSA 2019) was supported from resources for the popularization of scientific activities from the Minister of Science and Higher Education in the framework of agreement No 712/P-DUN/202019. 


\section{References}

Błędowski, P. (2002). Lokalna polityka społeczna wobec ludzi starszych. Monografie i Opracowania. Warszawa: Oficyna Wydawnicza Szkoły Głównej Handlowej.

Hellwig, Z. (1968). Zastosowanie metody taksonomicznej do typologicznego podziału krajów ze względu na poziom ich rozwoju oraz zasoby i strukturę wykwalifikowanych kadr. Przeglad Statystyczny, (4), 307-327.

Informacja o sytuacji osób starszych w Polsce za rok 2017, 8. Retrieved 3.09.2019 from www.senior. gov.pl:

Miasta przyjazne starzeniu: Przewodnik. (2014). Warszawa: Fundacja Res Publica im. Henryka Krzeczkowskiego.

Szołtysek, J., and Trzpiot, G. (2019). Miasta przyjazne seniorom. Katowice: Wydawnictwo Uniwersytetu Ekonomicznego w Katowicach.

Trzpiot, G., Szołtysek, J., Twaróg, S., and Ojrzyńska, A. (2015). Wielowymiarowa analiza oceny jakości życia w mieście. In Modelowanie wielowymiarowych struktur danych i analiza ryzyka (pp. 118-127). Katowice: Wydawnictwo Uniwersytetu Ekonomicznego.

Trzpiot, G., and Szołtysek, J. (2016). Bezpieczeństwo ludzi starszych w smart city. Prace Naukowe Uniwersytetu Ekonomicznego we Wrocławiu, (483), 209-226.

World Health Organization. (2007). Global age-friendly cities: A guide. Geneva.

World Health Organization. (2010). United Nations Human Settlements Programme (UN-Habitat). Hidden cities: Unmasking and overcoming health inequities in urban settings. Kobe: World Health Organization. Retrieved 17.04.2014 from http://www.who. int/kobe_centre/publications/hidden_cities2010/en/

World Health Organization. (2011). Global health and ageing. World Health Organization \& U.S. National Institute of Aging. Geneva. Retrived 3.06.2014 from http://www. who.int/ageing/publications/global_health.pdf

World Health Organization. (2015). Measuring the age-friendliness of cities: A guide to using core indicators. WHO Library Cataloguing-in-Publication Data.

World population ageing. (2013). New York: United Nations Department of Economic and Social Affairs, Population Division. Retrieved 28.05.2014 from http:// www.un.org/en/development/desa/ population/publications/pdf/ageing/WorldPopulationAgeingReport2013.pdf

\section{SENIORZY W MIASTACH I ANALIZA MIAST PRZYJAZNYCH SENIOROM DLA WYBRANYCH MIAST POLSKICH - ODPORNE PODEJŚCIE TAKSONOMICZNE}

Streszczenie: Celem artykułu jest ocena wybranych dużych miast w Polsce jako przyjaznych seniorom. Korzystając z prognozy ludności miejskiej na lata 2017-2030 opublikowanej w 2017 r., wraz z dostępną bazą danych, przeprowadzono własne analizy dla wybranych miast w Polsce. Dodatkowo w opisie miast przyjaznych seniorom przyjęto, że punktem wyjścia jest definicja WHO, która wskazała cztery główne kryteria określające, czy dane miasto można uznać za przyjazne dla osób starszych. W mieście przyjaznym dla seniorów przyjmowane regulacje, usługi, środowisko i kreowanie odpowiednich struktur wspierają proces aktywnego starzenia się i pomagają mieszkańcom. Na potrzeby badań, uwzględniając powyższe cele i na podstawie opublikowanych źródeł, stworzono model opisowy. W badaniu oceniono wybrane miasta polskie jako miasta przyjazne seniorom, stosując odporne podejście taksonomiczne.

Słowa kluczowe: osoby starsze, bezpieczeństwo seniorów, odporna analiza taksonomiczna.

Quote as: Trzpiot, G. (2020). Seniors in cities and senior-friendly cities analysis for selected Polish cities - robust taxonomic approach. Econometrics. Ekonometria. Advances in Applied Data Analysis, 24(2). 